\title{
EDITORIAL
}

\section{Reviewing and Speculating on Public Space Futures through a New Lens}

\author{
Luisa Bravo \\ City Space Architecture, Italy \\ luisa.bravo@cityspacearchitecture.org \\ Maggie McCormick, Fiona Hillary \\ RMIT University, School of Art, Australia \\ maggie.mccormick@rmit.edu.au | fiona.hillary@rmit.edu.au
}

\begin{abstract}
This 'Art and Activism in Public Space' special issue of The Journal of Public Space reflects the dilemmas of the COVID-19 era and its impact on public space across the globe. While this issue's beginnings were pre-COVID, its publication was impacted by the pandemic both in its timeline and in how the portfolios and articles will be read through a new lens. This issue presents a collection of projects from across Estonia, Finland, Italy, China, United Kingdom, Australia, Spain, Mexico, United States of America, Colombia, Japan, Cyprus, Hong Kong, Singapore, Canada, Denmark, Germany, Greece, Poland, Egypt. The portfolios and articles assert the important role of multidisciplinary inquiry and the integration of practice and theory in the investigation into and the active creation of, the complex and changing state of public space. The experience of a global pandemic and the increase in digital networks has led to a reviewing of the role of public space and fostered speculation on new approaches to public space culture.
\end{abstract}

Keywords: multidisciplinary inquiry, integration of practice and theory, COVID-I9 pandemic, public space futures

To cite this article:

Bravo, L., McCormick, M., Hillary, F. (2020) Reviewing and Speculating on Public Space Futures through a New Lens, The Journal of Public Space, 5(4), I-6, DOI 10.3289I/jps.v5i4.I 445

This work is licensed under a Creative Commons Attribution - Non Commercial 4.0 International License https://creativecommons.org/licenses/by-nc/4.0/ 
As planning for this 2020 'Art and Activism in Public Space' issue began pre COVID-19, it did not set out to specifically address the impact of a pandemic on art, activism, and public space. At the time of this issue's publication, impacted on by waves of this pandemic and by extensive lockdowns, we are still experiencing COVID-19 globally. As such, the pandemic experience now shapes our perspective on public space and how the portfolios and articles in this issue are viewed.

The experience of the virus has focused our view firmly on public space by creating reflective spaces, facilitated by both windows and screens. On the one hand, as we looked out windows over empty streets and on the other hand, as we 'met' through vastly increased digital public space. This digital public space has kept us connected as global citizens and created the opportunity to re-think our relationship to public space and to investigate new answers to old questions as well as pose new questions.

- When public space is lost, what does society lose?

- When we return, to the new 'covid normal' public space, what will we have learnt?

- $\quad$ From our covid experience, how might we now re-think public space? For example: What happens when we consider public space not as a backdrop to our daily lives - but as an entanglement of relationships - human and nonhuman, as a complex living ecology?

Digital public space has been the platform for speculation on the potential of physical public space and how we might shape the new 'covid normal' public domain.

Such questions were taken up by The Journal of Public Space during the pandemic through the online initiative titled '2020: A Year Without Public Space Under the COVID-19 Pandemic', jointly developed by City Space Architecture and The University of Hong Kong, School of Architecture, co-funded by the RGC Fund Project: 'Built Environment and Planning for Healthy Cities' and curated by Luisa Bravo and Hendrik Tieben'. Universities, academics and artists from across the world were drawn together during the pandemic through a series of twenty webinars, from May to September, to share their experiences and expertise in thinking about the future, attracting 2700+ attendees from over 80 countries. One of the webinars was curated by the editors of the 'Art and Activism in Public Space' special series, Luisa Bravo, Maggie McCormick and Fiona Hillary, in association with Katrina Simon, Associate Dean, Landscape Architecture at RMIT University: 'Speculative Cities: thinking forward' under the 'Innovative Approaches and Creative Practice' section of the webinar series, explored speculative art and design practices and the role of speculation in re-imagining the future of public space ${ }^{2}$. This mode of thinking takes a critical approach to the acquisition of knowledge through practice, to contribute to contemporary understanding of the times we live in, and will live in. It questions existing paradigms, asks 'what if, and seeks to imagine and create alternative futures.

The articles and portfolios included in this issue of 'Art and Activism in Public Space' alert us to a wide range of perspectives and possibilities. What are highlighted are existing

\footnotetext{
' The summary of the initiative is available on The Journal of Public Space https://www.journalpublicspace.org/index.php/jps/navigationMenu/view/covid-19-program. The initiative included a special issue of The Journal of Public Space (2020) https://www.journalpublicspace.org/index.php/jps/issue/view/76

${ }^{2}$ A summary of the webinar is available on The Journal of Public Space: https://www.journalpublicspace.org/index.php/jps/navigationMenu/view/webinar6-summary
} 
public space dilemmas, which have now been brought into the spotlight through the COVID-I 9 experience. By drawing on perspectives and practices from across the globe, including writers, practitioners, and projects from Estonia, Finland, Italy, China, United Kingdom, Australia, Spain, Mexico, United States of America, Colombia, Japan, Cyprus, Hong Kong, Singapore, Canada, Denmark, Germany, Greece, Poland, Egypt, this issue serves as a snapshot of site-specific responses to place and societal issues played out across a richly diverse global public space - as a shared speculative space. A series of portfolios and articles by artists and academics emphasize the importance of integrating artistic theory and practice with theoretical investigation, as equal research tools and equal perspectives. These perspectives play an important role alongside those of urban planners and administrators, architects and engineers, designers, and landscapers, to create a deeper level of understanding of the complexity of public space from its practicalities to its poetics. Public space artistic practice sits close to everyday people, who make the space their own. It reflects their unity and diversity, their common goals, and conflicts. It stops us in our tracks, by creating question marks in our shared spaces. It makes us think ... and act. The writers in this issue present concepts that employ a wide range of socially integrated practices that utilise such actions as play, surprise and meditation to draw attention to the anomalies within public space and pose speculative possibilities. Photography, sculpture, film, and performance are amongst the practices employed.

Each issue of 'Art and Activism in Public Space' features four artists who have undertaken the RMIT Master of Arts, Art in Public Space program. MAPS is a unique international degree with a focus on critical engagement with contemporary urban public space and culture by bringing together education and research as well as theory and practice and encouraging active collaboration between practitioners and the community. As such it draws together a cohort of those with skills in visual practice, performance, video, sound, creative arts, writing, design, architecture, fashion, and curatorial and cultural management fields in undertaking its practice based creative public space inquiry. MAPS is closely aligned with the RMIT School of Art's research group CAST - Contemporary Art and Social Transformation, as a hub for artistic practices that intersect with issues of equity, access and democracy and radical ways of knowing and being, with an interest in the public sphere, the intersection of human and nonhuman forces, global indigeneity, and the role of education as a change-agent. The four selected artists and projects featured in this issue reflect the MAPS approach and employ architecture, philosophy, textiles and playful performance to interpret 'activism' and 'public space' through the lens of their specific practice, experience, and cultural heritage - from Japan to Colombia to Vietnam to Australia.

Such art practice now complements a sharper public awareness that grew during the pandemic, of the spaces we share, the way we use, or do not use them, as well as what might be done in these spaces. In Melbourne for example many more people began to use roundabouts, nature strips and small patches of grassed areas that were usually not thought of in this way. In Italy, apartment balconies became re-defined as spaces connected by the sound of singing. While our movements were restricted, our appreciation of what we had lost, increased. As restrictions eased in some places such as Melbourne, parklets cropped up as café spaces occupying what were once viewed as sacrosanct car parking spaces. The public space of roads and streets is being re-claimed, as public spaces more generally are being re-thought. These 'new' places then become linked to ideas of community ownership 
and begin to re-assert community action. Such small reviewing of the public domain potentially leads to greater societal re-thinking and action. One such example of the reclaiming of public space is the Parklet via Curiel I3/d in Bologna in Italy, implemented by City Space Architecture, as a temporary public space, for non-profit purposes and open to all. The parklet is located in front of the Public Space Museum, a brand-new venue for public space culture co-founded by City Space Architecture and Genius Saeculi, a for-profit company working on Digital Humanities, as a transdisciplinary opportunity for public space inquiry and practice through art and technology. The Museum was established during the COVID-19 pandemic through the renovation of an old supermarket.

Together with the 'Art and Activism in Public Space' special series of The Journal of Public Space, such initiatives play an important role in creating global networks and fostering interdisciplinary investigations into the crucial role played by public space within rapidly changing societies across the world.

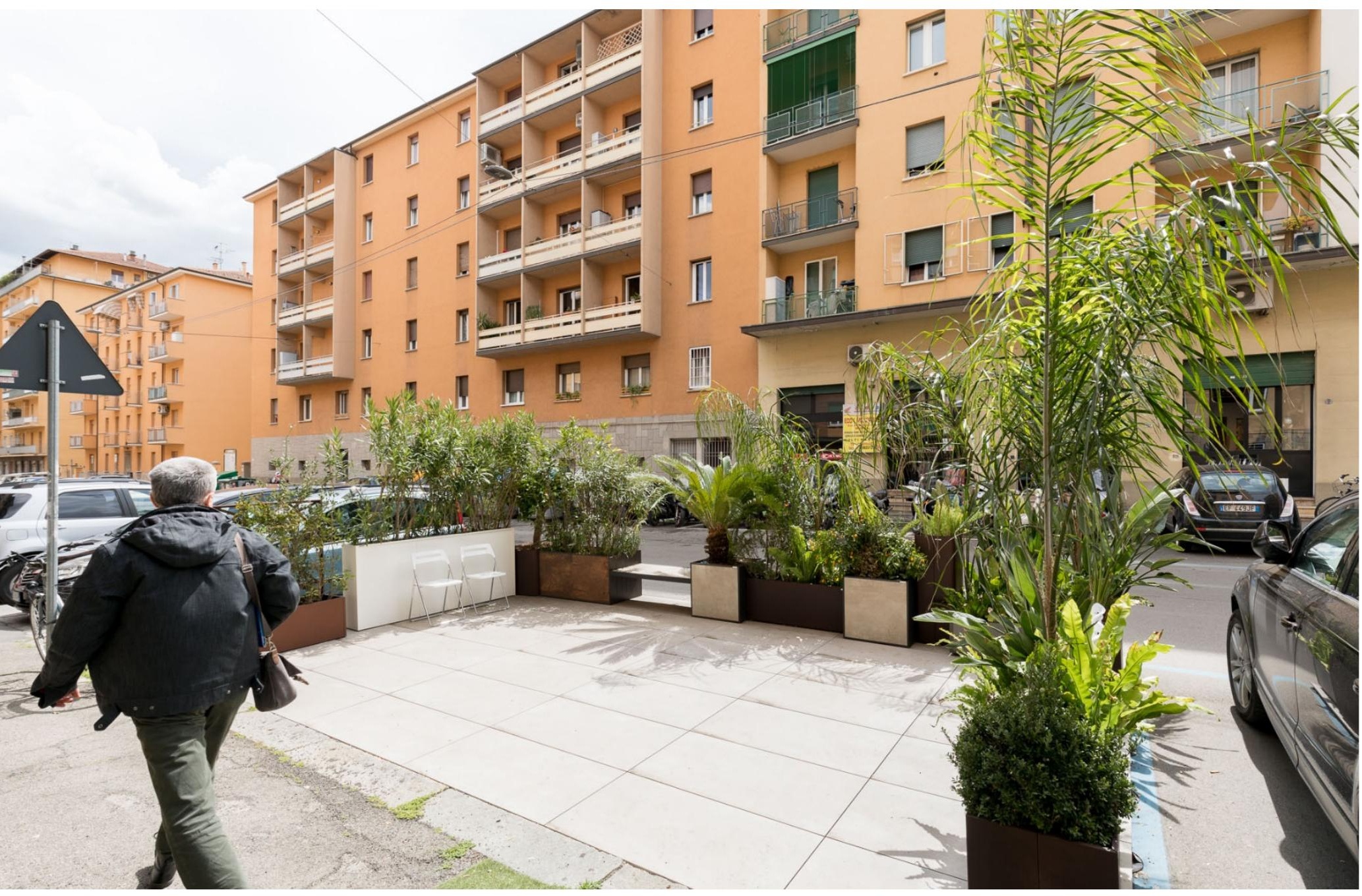

Figure I. The first-ever Parklet in the city of Bologna, in the Porto-Saragozza neighbourhood, via Curiel I3/d, in front of the Public Space Museum, the creative headquarters of City Space Architecture.

The parklet was designed by Luisa Bravo and implemented by City Space Architecture, as part of A-Place. Linking places through networked artistic practices, co-funded by the Creative Europe programme of the European Union. Read more: https://www.a-place.eu/en/placemaking-activity/I7

Picture by Elettra Giulia Bastoni. 

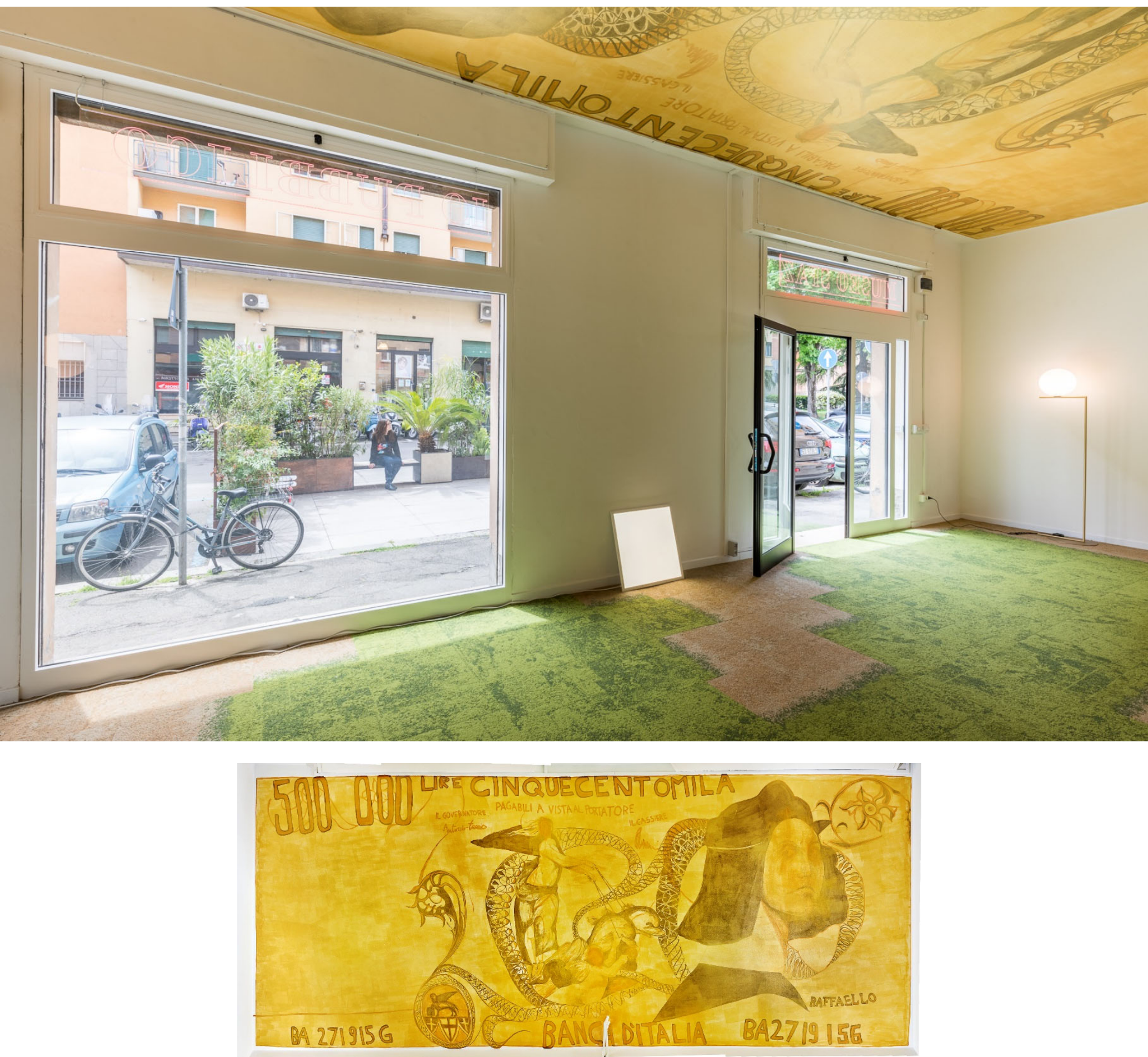

Figure 2 (top). The Public Space Museum in Bologna, established by City Space Architecture and Genius Saeculi, by renovating an old supermarket, during the COVID-19 pandemic - www.museospaziopubblico.it. The Public Space Museum is curated by Luisa Bravo. Picture by Elettra Giulia Bastoni.

Figure 3 (down). The Public Space Museum is enriched with the art-work of the well-known Italian artist Flavio Favelli, with a fresco on the ceiling named Raffaello 500, depicting in a giant scale the banknote of 500.000 Italian lira with the face of Raffaello Sanzio, recognized by the critics as the most spiritual Italian artist. This art-work is giving a permanent identity to the Museum and is adding value to the spatial experience, playing on imagination and enchantment. Picture by Marco Pintacorona. 
"A museum is a non-profit, permanent institution in the service of society and its development, open to the public, which acquires, conserves, researches, communicates and exhibits the tangible and intangible heritage of humanity and its environment for the purposes

of education, study and enjoyment". ICOM (International Council of Museums) Statutes, adopted in 2007

"Museums have become key public spaces that, beyond hosting exhibitions, promote debates and dynamic activities for wide variety of publics".

Judy Wajcman, Professor of Sociology at the London School of Economics and Political Sciences (LSE)

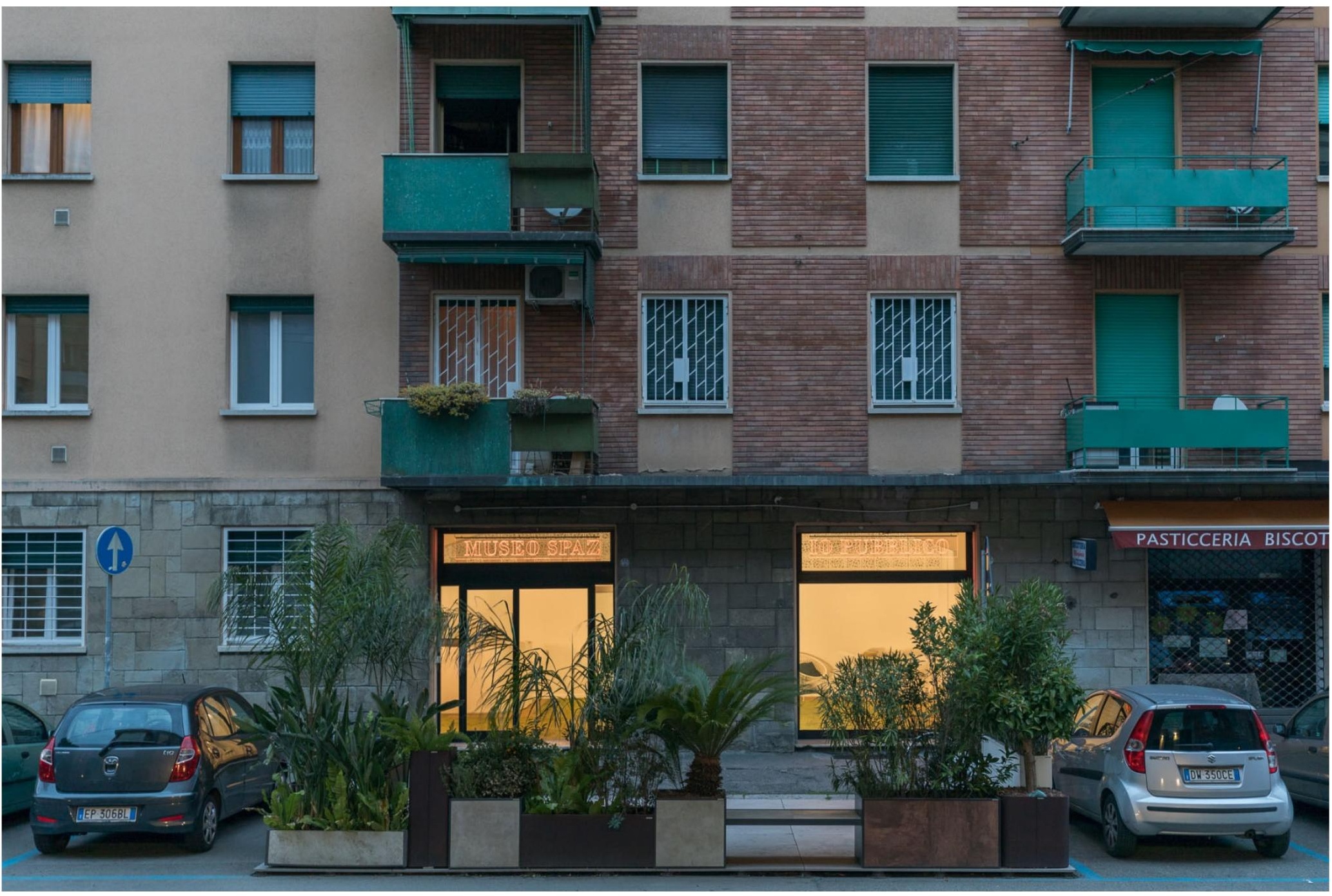

Figure 4. The Parklet in front of the Public Space Museum in Bologna.

Picture by Elettra Giulia Bastoni.

\section{Acknowledgment}

The 'Art and Activism in Public Space' editors would like to thank all the writers who have contributed to this issue that has emerged out of a challenging time for all engaged in public space culture.

6 | The Journal of Public Space, 5(4), 2020| ISSN 2206-9658

City Space Architecture / UN-Habitat 